
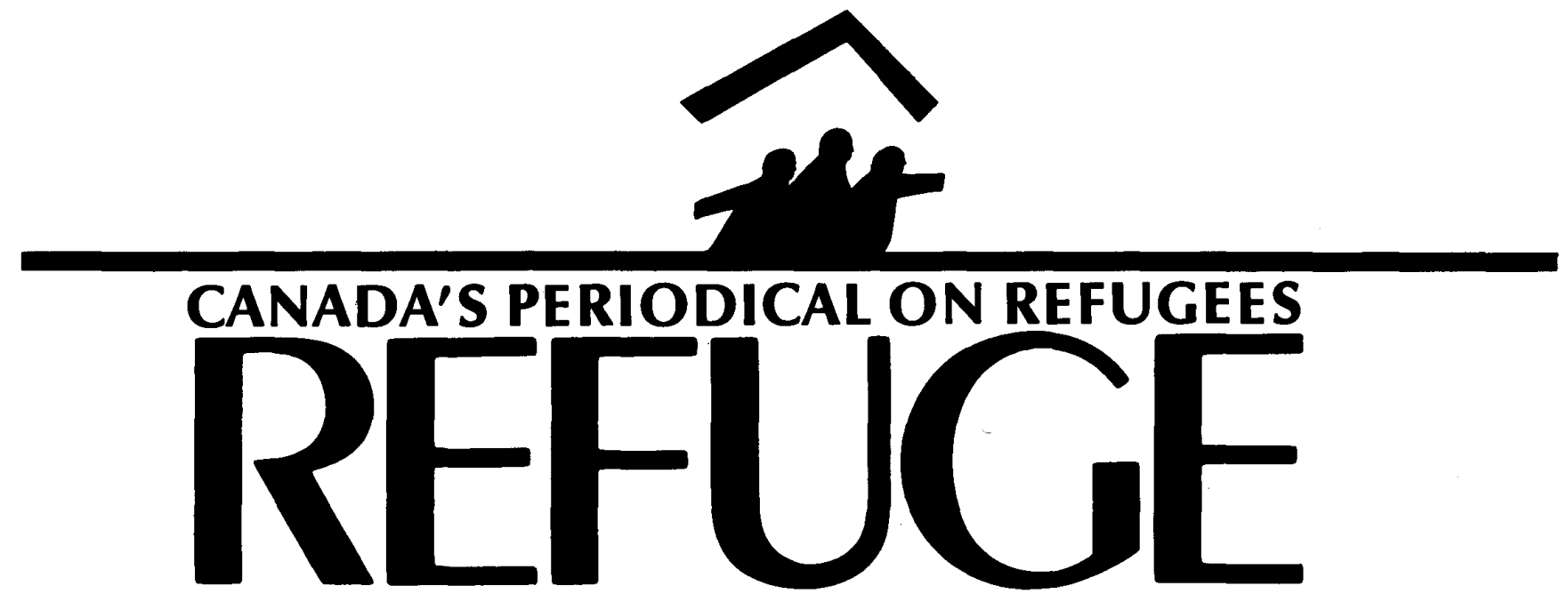

Vol. 9, No. 2

December 1989

\title{
CCR Fall Resolutions
}

The recent events in El Salvador, which have greatly exacerbated the human rights and refugee situation in that country, figured prominently in the resolutions passed by the Canadian Council for Refugees during its annual fall conference in Montreal on November 23-25. Two resolutions in particular dealt with the Salvadorean problem as part of the need to continue working to eliminate the root causes of the refugee crisis. It was also resolved to demand a halt to all deportations of Haitians living in Canada (ten days after the CCR conference the government stopped these deportations), to continue the monitoring of cases of deportation of refugee claimants deemed to be in need of protection, and to seek a review of Canada's commitments to the UNHCR now that the latter is experiencing its worst financial crisis.

\section{El Salvador}

Be it resolved that:

1. The Executive of the CCR take immediate steps to urge the Canadian Government to:

i) Continue efforts to bring about an immediate cease-fire and a negotiated settlement to the civil war and, in the meantime, maintain its suspension of government-to-government aid to El Salvador;

ii) Actively back the Organization of American States resolution urging all parties which have links to or interest in the region, to abstain from any actions which interfere with the achievement of a real and lasting peace in Central America;

iii) Support NGO relief efforts to provide immediate humanitarian aid to the people of El Salvador;

iv) Press the Salvadorean government to allow humanitarian organizations such as the International Red Cross and the Salvadorean churches to attend to civilians in the affected areas.
2. That the CCR and its member organizations immediately communicate by telegram, public opinion message, telephone call or letter to the Honourable Joe Clark, Minister of External Affairs, Government of Canada, Ottawa.

\section{Protection}

Be it resolved:

That the CCR call upon the Canadian government to undertake the following actions immediately:
1. That Canada increase its staffing in El Salvador to process urgent claims for protection, to process reunification cases originating with Salvadoreans in Canada, to ensure protection of Salvadoreans at refugee centres, and to ensure protection of persons approved by Canada in transit to the airport;

2. That Canada remove visa requirements and waive passport requirements for those persons in El Salvador needing urgent protection from Canada;

Continued on page 2

\section{IN THIS ISSUE:}

A Word About Naivety by Geza Tessenyi

The Evolution in Perception of the Role of the RHO by Sam Laredo, Elaine Pollock and Jan Marshall

An Appeal on the Merits by Michael Schelew

The Interpreters at the IRB by Alex Zisman

A Task Force on Overseas Selection by David Matas

Who Gets In? reviewed by Howard Adelman

page 3

page $4^{\prime}$

page 6

page 10

page 11

page 13 
3. That those arriving from El Salvador be processed for immediate landings, if this is their wish;

4. That a moratorium on deportations of Salvadoreans from Canada be announced immediately by the Minister;

5. That Salvadoreans in the backlog(s) be processed for immediate landing.

And that the CCR invite the ICCR and the $\mathrm{CCIC}$ and their member agencies to endorse these recommendations and urge the Canadian government through both the Ministers of Employment and Immigration and of External Affairs to implement these recommendations immediately.

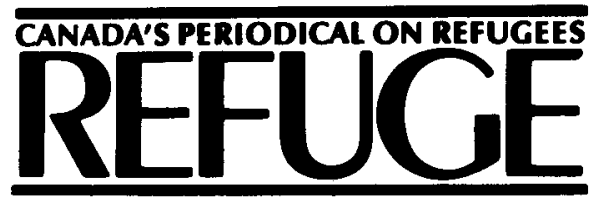

Centre for Refuge Studies, York University, Suite 234, Administrative Studies Building. 4700 Keele Street, North Yod, Onturio, Canada M3J 1 P3. Tel ephone: (416) 736-5663. Fax: (416) 736-5687. Electronic Mail Vis Bitnet Addres: REFUGE@YORKVM1

\section{Editor:}

Howard Adelman

Executive Editor:

Alex Zisman

Illustrations:

Herminio Ordóñez

Circulation Manager:

Helen Gross

Assistant to the Circulation Manager: Ching Man (C.M.) Wong

Refuge is dedicated to the encouragement of assistance to refugees by providing a forum for sharing information and opinion on Canadian and international issues pertaining to refugees. It is published four times a year by the Centre for Refugee Studies. It is a non-profit, independent periodical supported by private donations and by subscriptions. It is a forum for discussion, and the views expressed do not necessarily reflect those of its funders or staff.

All materials in Refuge may be reproduced without permission unless copyrighted or otherwise indicated. Credit should be given to the author or source, if named.

Subscription rates for one year are $\$ 20.00$ in Canada and US $\$ 25.00$ overseas. Please enclose payment with your order.

Logo design:

Dreadnaught Co-operative Inc., Toronto

Layout:

PAGES PLUS, 131 Atkinson, York University

Second Class Mail Registration N 5512 ISSN 0229-5113
And that the CCR invite the ICCR and the CCIC to participate in a joint committee to monitor protection of persons in El Salvador in the same manner as the joint committee which coondinated Canadian participation at the CIREFCA conference.

\section{Haitians in Canada}

\section{Threatened with}

\section{Deportation}

Be it resoloed:

That the Canadian Council for Refugees gathered in Montreal for the Annual General Meeting, November 23-25, 1989;

1. Deplores the lifting of the moratorium on deportation to Haiti announced by the Canadian government on October 5, 1989;

2. Demands an immediate halt to all deportations of Haitians now in Canada;

3. Requests the Minister of Employment and Immigration, Barbara McDougall, to make use of her discretionary powers to grant permanent residence on humanitarian grounds to those Haitians threatened with deportation.

Be it further resolved:

That the Canadian Council for Refugees further requests the Minister to undertake this action in accordance with Canada's international obligations with regard to the protection of refugees, respect for human rights, and with due concern for equitable treatment.

\section{Trace}

\section{Be it resolved.}

1. That the CCR continue its pilot program on "Trace" for a further 3 months, employing a person to set up a system of coordination to trace refugee claimants deemed to be in need of protection who have been deported from Canada to their country of origin or an intermediary country;

2. That the mechanism to be explored should include coondination of tracing actions in all regions of Canada involved and all persons and agencies involved, as well as an appropriate system for reporting on tracing actions and the collection of other relevant documentation or information as to where such documentation is easily avallable.

The person employed would assist the CCR Executive in proposing a way of financing the "Trace" mechanisms, e.g. through a consortium of agencies.

3. That the CCR seek financial support on a long term basis for these functions.

\section{The Financial Crisis in the UNHCR}

Be it resolved:

That the CCR executive and all member agencies communicate the following to the Minister of External Affairs:

1. A request to outline the government's actual and planned financial support of the general and special programs of the UNHCR.

2. A request to review current commitments to general and special programs, with a view to ensuring significant additional resources, commensurate with the increased needs of the UNHCR for both the 1989 and 1990 programs of the UNHCR.

\section{Government-Assisted Refugee Allocations by World Area 1989 and 1990}

Area

\section{Eastern Europe}

Southeast Asia

Latin America

Africa

The Middle East and West Asia

Funded management reserve and other world areas

Total
1989

3,400

3,000

3,400

1,000

1,800

400

13,000
1990

3,500

3,500

3,000

1,000

1,700

300

13,000 